\title{
Health care workers must protect patients from influenza by taking the annual vaccine
}

\author{
Ken Flegel MDCM MSc
}

$\mathrm{N}$ o right-thinking physician would ever knowingly harm a patient or fail to do some essential thing that would result in harm to a patient. This principle of medical practice is enshrined in the Latin dictum primum non nocere (first, do no harm). But when $55 \%-65 \%$ of physicians fail to take the annual seasonal influenza vaccine, ${ }^{1}$ they are exposing their patients to the risk of death from influenza. ${ }^{2}$ In Canada, the annual rate of influenza infection averages 5\%-10\% of the population; about 20000 hospital admissions result, and between 4000 and 8000 deaths are attributed to influenza. ${ }^{3}$ Each season, $20 \%$ of health care workers get influenza, and $28 \%-59 \%$ of young healthy adults who get it have asymptomatic or subclinical infections. Some of them may shed virus up to a day before symptoms appear. ${ }^{4}$ It is time that all people who work in a health care institution be vaccinated.

The benefits of vaccination in health care workers are clear. Efficacy rates are about $86 \%$ when the circulating strain and vaccine strain are well matched. ${ }^{4}$ There is less influenza (and mortality) among patients and staff and less time lost from work. An overview of 4 randomized trials showed a 5\%-20\% reduction in overall seasonal mortality in residents of chronic care institutions where staff vaccination rates were $51 \%-70 \%$ in intervention groups versus $3.5 \%-32 \%$ in control groups. ${ }^{5}$ Most patients in acute care hospitals are sicker than the ones in these studies and less able to resist a new infection or mount an immune response. Furthermore, a cost-benefit analysis from a health systems perspective found that for every US\$1000 spent on vaccination of health care workers, US\$1600 in costs was saved. ${ }^{6}$

Compulsory vaccination may be regarded as ethically questionable because it violates a person's autonomy. But in the case of influenza vaccination, the autonomy of health care workers comes into conflict with the best interests of the patient. Patients should come first, and in similar situations they do already. For example, a surgeon infected with HIV or a hepatitis virus is not allowed to operate.

Barriers to taking the annual vaccine include fear of getting sick or getting the flu from it, belief that the person "does not get the flu" or that the vaccine will not work, and belief that the vaccine has not been proven to protect patients. All of these reasons appear now to be untenable. The inactivated virus that is used cannot induce influenza. ${ }^{6}$ Adverse effects consist mainly of local reaction, low-grade fever and runny nose. Serious complications such as Guillain-Barré syndrome occur at a rate close to the background annual rate of 1 in 100000 , and strains with the potential to induce Guillain-Barré syndrome are generally avoided in creation of the vaccine. ${ }^{6,7}$
To justify compulsory vaccination, there must be an outbreak of serious illness; immunity levels must be low; the vaccine must be effective, safe and available; and vaccine uptake must be low. ${ }^{5.8}$ These conditions appear to be met for annual seasonal influenza. Exemptions could be granted for medical contraindications or for deeply held religious or philosophical convictions.

Campaigns and promotions have been attempted and have resulted in only a $22 \%-52 \%$ increase in vaccination rates. ${ }^{1}$ Compulsory programs for health care workers have resulted in participation rates above $95 \%$ in the leadership example of many Philadelphia teaching hospitals, as well as in a host of public and private American health care institutions. ${ }^{5}$ Public Health Ontario recently changed its guideline to recommend a mandatory program. ${ }^{9}$ The participation rate needs to be above $90 \%$ to prevent importation and to interrupt transmission within a hospital.

Our schools have shown us the way. During measles outbreaks, access to schools has been successfully denied to nonvaccinated children and staff. The time has come for health care institutions to demand that all health care workers be vaccinated. Our patients' lives depend on this change.

\section{References}

1. Lam P-P, Chambers LW, Pierrynowski MacDougall DM, et al. Seasonal influenza vaccination campaigns for health care personnel: systematic review. CMAJ 2010; 182:E542-8

2. Behrman AJ, Caplan AL, Coffin SE. Doctors choosing not to be vaccinated is choosing to do harm. BMJ 2011;343:d7198.

3. Public Health Agency of Canada. Influenza immunization - "the flu shot." Ottawa $(\mathrm{ON})$ : The Agency. Available: www.phac-aspc.gc.ca/im/iif-vcg/index-eng.php (accessed 2012 Oct. 12).

4. Thomas RE, Jefferson T, Demicheli V, et al. Influenza vaccination for healthcare workers who work with the elderly [review]. Cochrane Database Syst Rev 2006;(3): CD005187.

5. Talbot TR, Babcock H, Caplan AL, et al. Revised SHEA position paper: influenza vaccination of healthcare personnel. JSTOR. Infect Control Hosp Epidemiol 2010;31: 987-95-23.

6. Steckel CM. Mandatory influenza immunization for health care workers - an ethical discussion. AAOHN J 2007;55:34-9

7. Juurlink DN, Stukel TA, Kwong J, et al. Guillain-Barré syndrome after influenza vaccination in adults: a population-based study. Arch Intern Med 2006;166:2217-21.

8. Salmon DA, Teret SP, MacIntyre CR, et al. Compulsory vaccination and conscientious or philosophical exemptions: past, present and future. Lancet 2006;367:436-42.

9. Provincial Infectious Diseases Advisory Committee. Best practices for infection prevention and control programs in Ontario. 3rd ed. Toronto (ON): Public Health Ontario; 2012. Available: www.oahpp.ca/resources/documents/pidac/PIDAC-IPC_BP $\% 20$ Infection\%20Prevention\%20Control_English_Final_2012-10-03.pdf (accessed 2012 Oct. 12)

Competing interests: See www.cmaj.ca/site/misc/cmaj_staff.xhtml

Affiliations: Ken Flegel is Senior Associate Editor, CMAJ

Correspondence to: CMAJ editor,pubs@cmaj.ca

CMAJ 2012. DOI:10.1503/cmaj.121679 